University of Nebraska - Lincoln

DigitalCommons@University of Nebraska - Lincoln

Faculty Publications: Department of

Entomology

Entomology, Department of

6-1-2001

\title{
Oxidative Responses of Resistant and Susceptible Cereal Leaves to Symptomatic and Nonsymptomatic Cereal Aphid (Hemiptera: Aphididae) Feeding
}

\author{
Xinzhi Ni \\ Montana State University, Bozeman, MT \\ Sharron S. Quisenberry \\ Montana State University, Bozeman, MT \\ Tiffany Heng-Moss \\ University of Nebraska-Lincoln, thengmoss2@unl.edu \\ John P. Markwell \\ University of Nebraska-Lincoln, jmarkwell2@unl.edu \\ Gautam Sarath \\ University of Nebraska-Lincoln, Gautam.sarath@ars.usda.gov
}

See next page for additional authors

Follow this and additional works at: https://digitalcommons.unl.edu/entomologyfacpub

Part of the Entomology Commons

$\mathrm{Ni}$, Xinzhi; Quisenberry, Sharron S.; Heng-Moss, Tiffany; Markwell, John P.; Sarath, Gautam; Klucas, Robert; and Baxendale, Frederick P., "Oxidative Responses of Resistant and Susceptible Cereal Leaves to Symptomatic and Nonsymptomatic Cereal Aphid (Hemiptera: Aphididae) Feeding" (2001). Faculty Publications: Department of Entomology. 113.

https://digitalcommons.unl.edu/entomologyfacpub/113

This Article is brought to you for free and open access by the Entomology, Department of at DigitalCommons@University of Nebraska - Lincoln. It has been accepted for inclusion in Faculty Publications: Department of Entomology by an authorized administrator of DigitalCommons@University of Nebraska - Lincoln. 


\section{Authors}

Xinzhi Ni, Sharron S. Quisenberry, Tiffany Heng-Moss, John P. Markwell, Gautam Sarath, Robert Klucas, and Frederick P. Baxendale 


\title{
Oxidative Responses of Resistant and Susceptible Cereal Leaves to Symptomatic and Nonsymptomatic Cereal Aphid (Hemiptera: Aphididae) Feeding
}

\author{
XINZHI NI, SHARRON S. QUISENBERRY, TIFFANY HENG-MOSS,${ }^{1}$ JOHN MARKWELL, ${ }^{2}$ \\ GAUTAM SARATH ${ }^{2}$ ROBERT KLUCAS, $^{2}$ AND FREDERICK BAXENDALE ${ }^{1}$
}

Department of Entomology, Montana State University, Bozeman, MT 59717

\begin{abstract}
J. Econ. Entomol. 94(3): 743-751 (2001)
ABSTRACT The impact of the leaf-chlorosis-eliciting Russian wheat aphid, Diuraphis noxia (Mordvilko), and the nonchlorosis-eliciting bird cherry-oat aphid, Rhopalosiphum padi (L.), feeding on D. noxia-susceptible and -resistant cereals was examined during the period (i.e., 3, 6, and $9 \mathrm{~d}$ after aphid infestation) that leaf chlorosis developed. After aphid number, leaf rolling and chlorosis ratings, and fresh leaf weight were recorded on each sampling date, total protein content, peroxidase, catalase, and polyphenol oxidase activities of each plant sample were determined spectrophotometrically. Although R. padi and D. noxia feeding caused significant increase of total protein content in comparison with the control cereal leaves, the difference in total protein content between $R$. padi and D. noxia-infested leaves was not significant. Although R. padi-feeding did not elicit any changes of peroxidase specific activity in any of the four cereals in comparison with the control leaves, $D$. noxia feeding elicited greater increases of peroxidase specific activity only on resistant 'Halt' wheat (Triticum aestivum L.) and susceptible 'Morex' barley (Hordeum vulgare L.), but not on susceptible 'Arapahoe' and resistant 'Border' oat (Avena sativa L.). D. noxia-feeding elicited a ninefold increase in peroxidase specific activity on Morex barley and a threefold on Halt wheat $9 \mathrm{~d}$ after the initial infestation in comparison with control leaves. Furthermore, D. noxia feeding did not elicit any differential changes of catalase and polyphenol oxidase activities in comparison with either R. padi feeding or control leaves. The findings suggest that D. noxia feeding probably results in oxidative stress in plants. Moderate increase of peroxidase activity (approximately threefold) in resistant Halt compared with susceptible Arapahoe wheat might have contributed to its resistance to $D$. noxia, whereas the ninefold peroxidase activity increase may have possibly contributed to barley's susceptibility. Different enzymatic responses in wheat, barley, and oat to D. noxia and R. padi feeding indicate the cereals have different mechanisms of aphid resistance.
\end{abstract}

KEY WORDS Diuraphis noxia, Rhopalosiphum padi, protein content, peroxidase, catalase, polyphenol oxidase

OXIDATIVE RESPONSES OF plants to both abiotic (e.g., drought) and biotic (e.g., pathogens and herbivores) stresses have been reported on a number of crops. Drought stress increases peroxidase activities and malondialdehyde content (an indication of lipid peroxidation) in wheat plants (Zhang and Kirkham 1994). However, superoxide dismutase and catalase activities only increase at the early stage of drought conditions and then decrease under further drought conditions. The increase of peroxidase activities in rice, Oryza sativa L., wheat, Triticum aestivum L., barley, Hordeum vulgare L., cotton, Gossypium hirsutum L., and sugarcane, Saccharum spontaneum L., correlates with their resistance to pathogens (Chittoor et al. 1999). Pathogen-induced peroxidase activity is delayed or does not occur in the plants undergoing susceptible interac-

\footnotetext{
${ }^{1}$ Department of Entomology, University of Nebraska, Lincoln, NE 68583.

${ }^{2}$ Department of Biochemistry, University of Nebraska, Lincoln, NE 68583.
}

tions. The activation of plant foliar oxidases by noctuid herbivore feeding reduces nutritive quality of foliage on both foliage and fruit of tomato plants, Lycopersicon esculentum Mill (Felton et al. 1989). Further experiments suggested that polyphenol oxidase, proteinase inhibitors, lipoxygenase, and peroxidase decreased the nutritive value of tomato foliage to noctuid larvae (Duffy and Felton 1991, Duffey and Stout 1996). The incorporation of these enzymes into artificial diets reduces developmental performance of the noctuids. Insect feeding on soybean plants also elicited oxidative responses (Felton et al. 1994a, 1994b). Although a considerable amount of work has been reported on herbivores with chewing mouthparts, only a few studies have examined plant oxidative responses to sapfeeding insects. Feeding of twospotted spider mites, Tetranychus urticae Koch, on soybean, Glycine max (L.) Merr., elicits peroxidative responses in soybean leaves (Hildebrand et al. 1986), and resistance to $T$. urticae feeding and plant lipid peroxidation is strongly correlated in soybean genotypes. Both soybean resis- 
tance and lipid peroxidation were also correlated to carotenoid and chlorophyll losses. The herbivory by the phloem-feeding, threecornered alfalfa hoppers, Spissistilus festinus (Say), causes increases in the activities of several oxidative enzymes including lipoxygenases, peroxidases, ascorbate oxidase, and polyphenol oxidase on soybean plants (Felton et al. 1994a, 1994b).

Although oxidative responses of plants to herbivore feeding have been examined in many plants, no comparable work has been reported for cereals. The current report is part of our ongoing research to understand the mechanism of leaf chlorosis development elicited by the Russian wheat aphid,Diuraphis noxia (Mordvilko), and the mechanisms of aphid resistance in cereal plants. The objective of the present investigation was to compare the oxidative responses of $D$. noxia-resistant and -susceptible cereals to the chlorosis-eliciting $D$. noxia and nonchlorosis-eliciting bird cherry-oat aphid, Rhopalosiphum padi (L.), feeding.

\section{Materials and Methods}

Aphid Colony Maintenance. 'Stephens' (D. noxia susceptible) wheat was used for aphid colony maintenance. Plants were grown in pots $(10 \mathrm{~cm}$ diameter $)$ in a mixture of Sunshine soil mix No. 1 (SunGro Horticulture, Bellevue, WA) and sand (6:1 ratio). The colony of chlorosis-eliciting $D$. noxia was established originally using $D$. noxia collected near Scottsbluff, $\mathrm{NE}$, in 1994, and the nonchlorosis-eliciting $R$. padi colony was established using aphids collected near Lincoln, NE, in 1996. Plants and aphids were maintained in Plexiglas cages ( 30 by 15 by $15 \mathrm{~cm}$ ) in Percival growth chambers (Percival Scientific, Boone, IA) at $21 \pm 1^{\circ} \mathrm{C}, 40-50 \% \mathrm{RH}$, and a photoperiod of $16: 8$ (L:D) $\mathrm{h}$.

Growth of Cereal Plants. The four cereals used in the experiment were D. noxia-susceptible 'Arapahoe' and -resistant 'Halt' wheat, D. noxia-susceptible 'Morex' barley, and D. noxia-resistant 'Border' oat, Avena sativa $\mathrm{L}$. There were no previous reports on either resistance or susceptibility of R. padi to the four cereals used in this study. The impact of aphid feeding on cereal leaf total protein content, peroxidase, polyphenol oxidase, and catalase activities were examined spectrophotometrically. Changes in enzyme activities were monitored 3,6, and $9 \mathrm{~d}$ after the initial aphid infestation, which accompanied the development of D. noxia-elicited leaf rolling and chlorosis on the susceptible cereals.

Seeds of Arapahoe and Halt wheat, Morex barley, and Border oat were planted at the rate of three plants per Conetainer (SC-10 Super Cell Single Cell, $3.81 \mathrm{~cm}$ diameter by $21 \mathrm{~cm}$ deep, Stuewe \& Sons, Corvallis, OR) in the Plant Growth Center, Montana State University, Bozeman, MT. The Conetainers were filled with the previously described soil mixture and placed in Conetainer racks, leaving one space between two Conetainers to provide adequate light. Plants were watered uniformly from the bottom by placing a rack over a plastic tray ( 54 by 28 by $6 \mathrm{~cm}$ ) filled with water.
Before the initiation of aphid infestation, plants were thinned to one plant per Conetainer. Plants used in the experiment were grown under the conditions described above.

Infestation of Cereal Plants. At growth stage 12 (or two-leaf stage) (Zadoks et al. 1974), the second leaf of the cereal plants was infested with 0,20 apterous adult R. padi, or 20 apterous adult D. noxia. Aphid-infested plants were sampled on 3,6 , and $9 \mathrm{~d}$ after the initial infestation. All control and aphid-infested cereal plants were caged individually using polyethylene tube-cages ( $30 \mathrm{~cm}$ long by $4 \mathrm{~cm}$ diameter) and maintained in a Percival growth chamber under the conditions described above. On each sampling date, three plants (considered replications) were randomly selected for each of the 12 treatments (four cereals by three infestation levels). The number of aphids on the young leaf blade used for the enzyme assays (or per leaf) and on the whole seedling (or per plant) was recorded before removal. Aphid damage symptoms (leaf rolling and chlorosis) were then rated according to Webster et al. (1991) and Burd et al. (1993). The same-age young leaf blades were excised and weighed for the following protein and enzyme assays, because the young leaves had shown the most $D$. noxia damage.

Preparation of Leaf Tissue for the Assays. Excised leaf tissue was processed following the protocol described by Hildebrand et al. (1986). Cold potassium phosphate buffer $(0.1 \mathrm{M}, \mathrm{pH} 7.0)$ containing $1 \%$ (wt: vol) polyvinylpyrrolidone and $1 \%$ (vol:vol) Triton $\mathrm{X}-100$ was added to a chilled $\left(4^{\circ} \mathrm{C}\right)$ mortar and pestle containing the excised leaf sample. The leaflets were macerated with $1 \mathrm{ml}$ of the extracting buffer. Samples were further ground with another $1 \mathrm{ml}$ of the extracting buffer. In total, $2 \mathrm{ml}$ of the extracting buffer was used for each sample. An aliquot $(1.5 \mathrm{ml})$ of the extract was centrifuged at $10,000 \times g$ for $10 \min$ at $4^{\circ} \mathrm{C}$. The supernatant was frozen immediately for future total protein content and enzyme activity assays.

Protein and Enzyme Assays. The assays for total protein content and three oxidative enzymes (i.e., peroxidase, catalase, and polyphenol oxidase) were performed using a Genesys 5 spectrophotometer (Spectronic Instruments, Rochester, NY). All chemicals used in these assays were purchased from either Sigma Chemicals (St. Louis, MO) or Fisher (Houston, TX).

Total protein content was determined in duplicate using the Bradford assay described by Bollag and Edelstein (1991). Briefly, the assay mixture was made of $295 \mu \mathrm{l}$ of potassium phosphate buffer (0.1 M, pH 7.0), $500 \mu \mathrm{l}$ distilled water, $200 \mu \mathrm{l}$ Bradford reagent, and 5 $\mu \mathrm{l}$ of the plant extract. The absorbance of the assay mixture was recorded at $595 \mathrm{~nm}$. Total protein content was calculated using a standard curve generated from a series of bovine serum albumin concentrations (i.e., $0,2.5,5.0,7.5,10$, and $12.5 \mu \mathrm{g} / \mathrm{ml}$ ).

Peroxidase activity was determined by monitoring the increase in absorbance at $470 \mathrm{~nm}$ for $2 \mathrm{~min}$ at room temperature using a modified protocol described by Hildebrand et al. (1986) and Hori et al. (1997). The reaction was initiated by adding $200 \mu \mathrm{l}$ of $0.3 \%$ hy- 
Table 1. Number of aphids $( \pm$ SEM) on the leaf blade used in the enzyme assays and on the whole plant

\begin{tabular}{|c|c|c|c|c|c|c|c|c|c|}
\hline \multirow{3}{*}{ Cereals } & \multicolumn{9}{|c|}{ Days after infestation } \\
\hline & \multicolumn{3}{|c|}{$3 \mathrm{~d}$} & \multicolumn{3}{|c|}{$6 \mathrm{~d}$} & \multicolumn{3}{|c|}{$9 \mathrm{~d}$} \\
\hline & Control & R. padi & D. noxia & Control & R. padi & D. noxia & Control & R. padi & D. noxia \\
\hline \multicolumn{10}{|c|}{ No. of aphids per leaf blade used in enzyme assays } \\
\hline Arapahoe wheat & 0 & $13.7 \pm 1.7 \mathrm{abX}$ & $20.7 \pm 2.2 \mathrm{aX}$ & 0 & $25.7 \pm 6.7 \mathrm{aX}$ & $30.0 \pm 8.7 \mathrm{aX}$ & 0 & $23.0 \pm 9.5 \mathrm{aX}$ & $42.7 \pm 21.3 \mathrm{aX}$ \\
\hline Halt wheat & 0 & $15.7 \pm 1.3 \mathrm{abX}$ & $6.3 \pm 1.2 \mathrm{bY}$ & 0 & $26.0 \pm 3.2 \mathrm{aX}$ & $27.7 \pm 8.4 \mathrm{aX}$ & 0 & $53.7 \pm 21.1 \mathrm{aX}$ & $46.7 \pm 4.2 \mathrm{aX}$ \\
\hline Morex barley & 0 & $8.3 \pm 1.9 \mathrm{bY}$ & $15.7 \pm 1.7 \mathrm{aX}$ & 0 & $16.3 \pm 5.0 \mathrm{aX}$ & $49.0 \pm 23.2 \mathrm{aX}$ & 0 & $26.7 \pm 5.2 \mathrm{aX}$ & $66.0 \pm 13.9 \mathrm{aX}$ \\
\hline Border oat & 0 & $23.0 \pm 8.1 \mathrm{aX}$ & $22.0 \pm 7.0 \mathrm{aX}$ & 0 & $21.7 \pm 10.7 \mathrm{aX}$ & $20.0 \pm 9.0 \mathrm{aX}$ & 0 & $13.7 \pm 11.7 \mathrm{aX}$ & $53.7 \pm 9.9 \mathrm{aX}$ \\
\hline \multicolumn{10}{|c|}{ Total no. of aphids per plant } \\
\hline Arapahoe wheat & 0 & $31.0 \pm 2.3 \mathrm{aX}$ & $57.3 \pm 11.7 \mathrm{aX}$ & 0 & $87.3 \pm 13.0 \mathrm{aX}$ & $87.7 \pm 4.8 \mathrm{aX}$ & 0 & $156.3 \pm 10.1 \mathrm{abX}$ & $155.7 \pm 26.5 \mathrm{abX}$ \\
\hline Halt wheat & 0 & $38.0 \pm 5.2 \mathrm{aX}$ & $32.0 \pm 4.4 \mathrm{aX}$ & 0 & $73.7 \pm 10.3 \mathrm{aX}$ & $58.7 \pm 9.4 \mathrm{aX}$ & 0 & $166.7 \pm 13.5 \mathrm{aX}$ & $107.0 \pm 8.4 \mathrm{bcY}$ \\
\hline Morex barley & 0 & $26.7 \pm 5.5 \mathrm{aX}$ & $59.0 \pm 11.3 \mathrm{aX}$ & 0 & $95.3 \pm 1.7 \mathrm{aX}$ & $62.3 \pm 28.2 \mathrm{aX}$ & 0 & $132.3 \pm 2.3 \mathrm{bX}$ & $170.0 \pm 15.5 \mathrm{aX}$ \\
\hline Border oat & 0 & $32.0 \pm 10.6 \mathrm{aX}$ & $46.3 \pm 8.4 \mathrm{aX}$ & 0 & $105.3 \pm 25.7 \mathrm{AX}$ & $66.7 \pm 11.5 \mathrm{aX}$ & 0 & $132.3 \pm 8.2 \mathrm{bX}$ & $94.3 \pm 14.8 \mathrm{cX}$ \\
\hline
\end{tabular}

Means without standard error of mean \pm SEM denoted SEM $=0$; The means listed in the table were calculated from three samples $(n=$ 3 ). The means with different letters (a-c) within a column under each category were significantly different, whereas $R$. padi and $D$. noxia means with different letters (X-Y) within the same sampling date were not significantly different (LSD, $\alpha=0.05)$

drogen peroxide into a reaction mixture containing $300 \mu \mathrm{l}$ of $20 \mathrm{mM}$ guaiacol, $250 \mu \mathrm{l}$ of $0.1 \mathrm{M}$ potassium phosphate buffer ( $\mathrm{pH} 6.0), 240 \mu \mathrm{l}$ of distilled water, and $10 \mu \mathrm{l}$ of cereal enzyme extract. The peroxidase activity was monitored at $470 \mathrm{~nm}$ against a blank control containing all of the components of the reaction mixture except the cereal enzyme extract. The peroxidase specific activity (pmol $65 \mathrm{~min}^{-1} \mathrm{mg} 65$ protein $^{-1}$ ) was then calculated using the molar absorptivity of $26.6 \times 10^{3} \mathrm{M}^{-1} \cdot \mathrm{cm}^{-1}$ for guaiacol at $470 \mathrm{~nm}$.

Catalase activity was measured according to Chance and Maehly (1955) and Hildebrand et al. (1986). Catalase activity was determined by measuring the decrease in absorbance that reflects the decomposition of hydrogen peroxide catalyzed by catalase. Catalase activity was monitored at $240 \mathrm{~nm}$ for 2 $\mathrm{min}$ at the room temperature after initiation of the reaction. Enzymatic activity was initiated by adding 50 $\mu \mathrm{l}$ of cereal enzyme extract into the reaction mixture containing $500 \mu \mathrm{l}$ of potassium phosphate buffer $(0.1$ $\mathrm{M}, \mathrm{pH}$ 6.5), $250 \mu \mathrm{l}$ of distilled water, and $200 \mu \mathrm{l}$ of 75 $\mathrm{mM}$ hydrogen peroxide. The enzyme activity was measured against a blank reaction mixture containing no enzyme extract. The catalase specific activity $\left(\mathrm{pmol} \cdot \mathrm{min}^{-1} \cdot \mathrm{mg}\right.$ protein ${ }^{-1}$ ) was calculated using the molar absorptivity of $43.6 \mathrm{M}^{-1} \cdot \mathrm{cm}^{-1}$ for hydrogen peroxide at $240 \mathrm{~nm}$.

Polyphenol oxidase activity was determined by measuring the increase of absorbance at $470 \mathrm{~nm}$ for 2 $\min$ at the room temperature. We modified a protocol described by Hori et al. (1997). The reaction was started by adding cereal enzyme extract in a cuvet containing $500 \mu \mathrm{l}$ of $1.6 \%$ catechol in potassium phosphate buffer $(0.1 \mathrm{M}, \mathrm{pH} 6.0), 250 \mu \mathrm{l}$ of distilled water, and $200 \mu \mathrm{l}$ of potassium phosphate buffer $(0.1 \mathrm{M}, \mathrm{pH}$ 6.0 ). The assay was optimized using different amounts of plant samples, that is, $20 \mu \mathrm{l}$ for 3 - and 6-d samples, and $25 \mu \mathrm{l}$ for 9 -d samples. The enzyme activity was monitored against a blank containing no cereal enzyme extract. The polyphenol oxidase activity was presented as $\Delta \mathbf{A}_{470} \cdot \min ^{-1} \cdot \mathrm{mg}_{\text {protein }}{ }^{-1}$.

Experimental Design and Data Analysis. This was a three-factor experiment with repeated measures on one factor, which was also called a special type of split-plot design to observe the effect of experimental factors at successive periods of time (Neter et al. 1985). The experiment included four cereals, three types of infestations, and three sampling dates. Three plants (or replications) were used for each treatment on each sampling date. The data were analyzed using PROC GLM procedure of SAS software (SAS Institute 1989) followed by TEST statements to ensure correct error terms used in assessing main effect of each experimental factor (Cochran and Cox 1957). Although aphid data were compared only between R. padi and $D$. noxia infestations, all plant data were compared among control and R. padi- and D. noxia-infested leaves. The means of aphid numbers, leaf rolling and chlorosis data, and fresh leaf weight were separated by the least significant difference (LSD) test $(\alpha=0.05)$.

\section{Results}

Aphid Population Development. Because cerealby-infestation-by-sampling date interaction did not significantly $(F=0.62 ; \mathrm{df}=6,32 ; P=0.7109)$ affect the number of aphids per leaf, main effect of each experiment factor was analyzed. Although the sampling date (or infestation duration) $(F=10.22$; $\mathrm{df}=$ $2,32 ; P=0.0004)$ showed a significant effect on aphid number per leaf, cereal type did not affect aphid population growth $(F=0.35$; $\mathrm{df}=3,6 ; P=0.7929)$. The total number of aphids per plant was similar to the number of aphids per leaf. The cereal-by-infestationby-sampling date interaction was not significant $(F=$ $1.74 ; \mathrm{df}=6,32 ; P=0.1434$ ), while the sampling date showed a significant effect on aphid numbers per plant $(F=10.22 ; \mathrm{df}=2,32 ; P=0.0004)$. But, neither aphid species $(F=1.86 ; \mathrm{df}=1,6 ; P=0.2102)$ nor did cereal type $(F=1.96 ; \mathrm{df}=3,6 ; P=0.2219)$ affect the total number of aphids per plant.

The increase of aphid numbers occurred through the three sampling dates was likely the result of natural aphid population development that differed in the two species. Greater variation in the number of aphids per plant in both species was observed on the 9-d sampling 


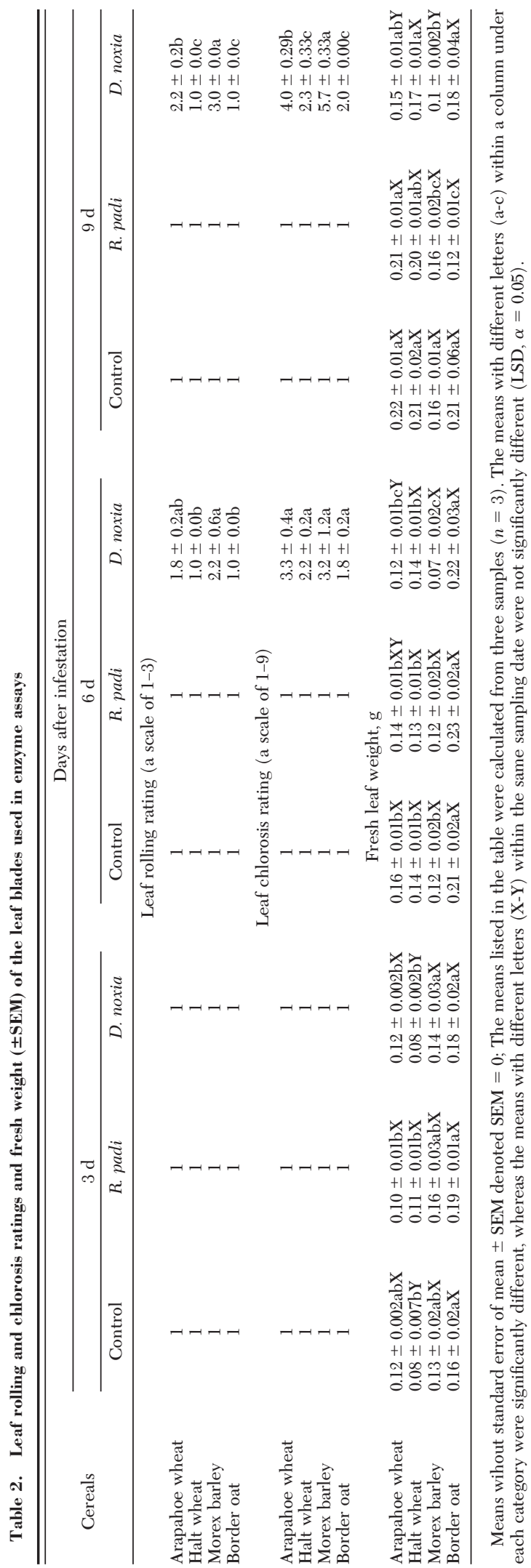

date than on either 3- or 6-d sampling dates (Table 1). A greater number of $D$. noxia than $R$. padi were recorded on the young leaf blades of Morex barley used for the enzyme assays, but no difference was found on the whole Morex barley plants (Table 1). This indicates that $D$. noxia preferred young leaf blades, whereas $R$. padi did not. However, on the last $(9 \mathrm{~d})$ sampling date, a greater total number of R. padi than D. noxia were recorded on Halt wheat plants (Table 1). This result suggests that Halt wheat was resistant to $D$. noxia feeding, but might not be resistant to $R$. padi.

Effect of Aphid Feeding on Plant Growth. Leaf rolling and chlorosis ratings were compared only among the four cereals because only $D$. noxia inflicted such symptoms (Table 2). Leaf rolling rating was significantly affected by cereal type $(F=27.15 ; \mathrm{df}=3$, $6 ; P=0.0007)$ and the sampling date $(F=19.10 ; \mathrm{df}=$ 2,$6 ; P<0.0001$ ), as was leaf chlorosis rating (cereal type: $F=32.04 ; ; \mathrm{df}=3,6 ; P=0.0004$; the sampling date: $F=34.98 ; \mathrm{df}=2,6 ; P<0.0001)$. Although $D$. noxia-elicited leaf rolling was only observed on susceptible Arapahoe wheat and Morex barley, leaf chlorosis occurred on all cereals examined, but varied in chlorosis ratings (Table 2). Also, D. noxia-elicited chlorosis did not appear on plants until $6 \mathrm{~d}$ after infestation. D. noxia feeding elicited significantly greater leaf chlorosis ratings on susceptible cereals (i.e., Arapahoe wheat and Morex barley) than on resistant cereals (i.e., Halt wheat and Border oat) (Table 2). Among the four cereals examined, D. noxia caused the most severe leaf chlorosis on Morex barley and the least chlorosis on Border oat.

Fresh leaf weight data were analyzed among all types of infestations (i.e., the control, R. padi-infested, and $D$. noxia-infested cereals) to assess the aphid impact on plant growth. Although cereal-by-infestationby-sampling date interaction did not significantly $(F=$ $1.11 ; \mathrm{df}=12,48 ; P=0.3766)$ affect fresh leaf weight, the sampling date $(F=14.66 ; \mathrm{df}=2,48 ; P<0.0001)$, the infestation type $(F=4.35 ; \mathrm{df}=2,16 ; P=0.0311)$, and the cereal type $(F=17.46 ; \mathrm{df}=3,6 ; P=0.0023)$ had all significantly affected fresh leaf weight. On the 9-d sampling date, D. noxia-feeding elicited a significant loss of fresh leaf weight on the susceptible Arapahoe wheat and Morex barley in comparison with the control, but not on the resistant Halt wheat and Border oat (Table 2). Furthermore, R. padi-feeding did not affect the fresh leaf weight as much as $D$. noxia.

Leaf Protein Content. Although the cereal-by-infestation-by-sampling date interaction had no significant effect $(F=1.37 ; \mathrm{df}=12,48 ; P=0.2135)$ on leaf total protein content, the sampling date had significantly $(F=86.60 ; \mathrm{df}=2,48 ; P<0.0001)$ affected the protein content. The infestation type also showed a significant $(F=4.02 ; \mathrm{df}=2,16 ; P=0.0385)$ impact on total protein content in the leaves used for the enzyme assays. Mean of total protein content $\left(\mathrm{mg} \cdot \mathrm{g}^{-1}\right.$ fresh weight) for the control cereal leaves was $17.55 \pm 1.03$, whereas $D$. noxia infested cereals was $20.03 \pm 1.14$, and R. padi infested cereals was $20.69 \pm 0.96$ (Fig. 1). Although both R. padi and D. noxia infestations caused 


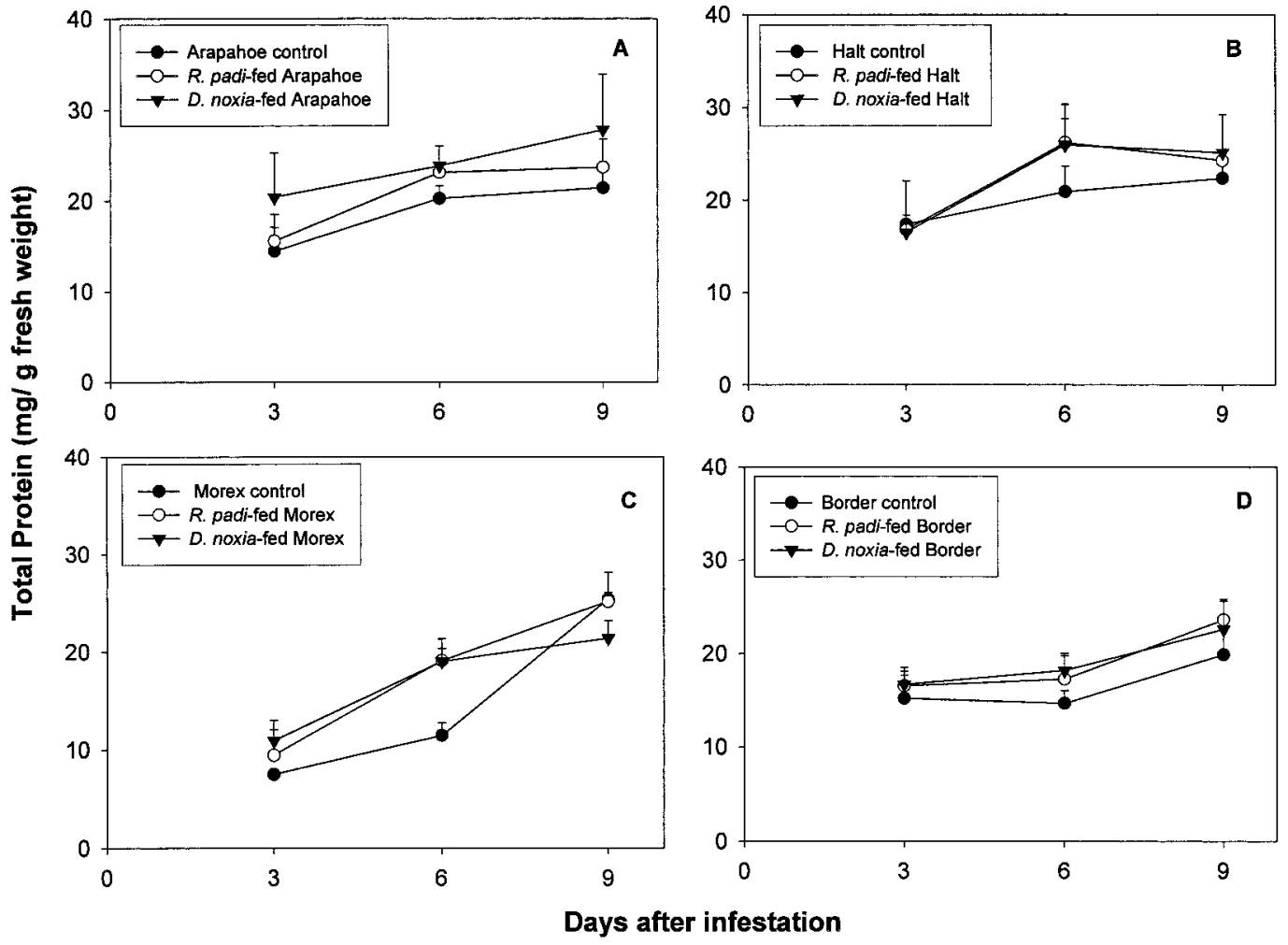

Fig. 1. Total protein content $\left(\mathrm{mg} \cdot \mathrm{g}^{-1}\right.$ fresh leaf weight) from aphid-infested (i.e., 0, 20 R. padi, or 20 D. noxia) cereal leaves on 3,6, and $9 \mathrm{~d}$ after the initial infestation. Error bars represent standard error of the mean ( \pm SEM) for a data point $(n=3)$. (A) Arapahoe wheat (D. noxia susceptible). (B) Halt wheat (D. noxia resistant). (C) Morex barley (D. noxia susceptible). (D) Border oat (D. noxia resistant). R. padi denotes the bird cherry-oat aphid, Rhopalosiphum padi L., and D. noxia denotes the Russian wheat aphid, Diuraphis noxia (Mordvilko).

a significant increase of total protein content in comparison with the control, there was no significant difference in protein content between R. padi- and D. noxia-infested leaves $(F=3.51 ; \mathrm{df}=1,16 ; P=0.0981)$ (Fig. 1). Cereal type also influenced leaf protein content significantly $(F=11.67 ; \mathrm{df}=3,6 ; P=0.0065)$. The wheat leaves (Fig. $1 \mathrm{~A}$ and B) had higher protein content than the barley (Fig. 1C) and oat leaves (Fig. 1D).

Peroxidase Activity. Although the cereal-by-infestation-by-sampling date interaction $(F=1.56 ; \mathrm{df}=12$, $48 ; P=0.1345)$ and the sampling date $(F=0.003 ; \mathrm{df}=$ $2,48 ; P=0.9974)$ did not significantly affect peroxidase specific activity, the infestation type $(F=46.40$; $\mathrm{df}=2,16 ; P<0.0001)$ and cereal type $(F=13.40$; $\mathrm{df}=$ $3,6 ; P<0.0045)$ had significantly affected the peroxidase activity. $D$. noxia infestation caused greater increase of peroxidase activities on Halt wheat and Morex barley than on Arapahoe wheat and Border oat in comparison with the control and $R$. padi-infested leaves (Fig. 2). Of the four cereals tested, susceptible Arapahoe wheat showed less D. noxia-elicited increase (Fig. 2A) than resistant Halt wheat (Fig. 2B). The peroxidase activity increased as $D$. noxia infestation continued on Halt wheat (Fig. 2B) and Morex barley (Fig. 2C). D. noxia-infested Morex barley leaves showed the greatest increase of peroxidase activities, as high as ninefold, when compared with the control on day 9 (Fig. 2C). D. noxia-infested Halt wheat showed approximately threefold increase in peroxidase activity on day 9 . In contrast, Border oat showed no significant increase of peroxidase activity on any sampling dates (Fig. 2D). The increase of peroxidase activity in $D$. noxia-infested wheat and barley accompanied the damage symptom development (Fig. 2 B and C) on 6- and 9-d sampling dates, but not in Arapahoe wheat and Border oat (Fig. 2 A and D).

Catalase Activity. In addition, the cereal-by-infestation-by-sampling date interaction showed no effect on catalase activity $(F=0.44 ; \mathrm{df}=12,48 ; P=0.9377)$, neither infestation type $(F=1.38$; $\mathrm{df}=2,16 ; P=$ $0.2798)$ nor did cereal type $(F=1.80 ; \mathrm{df}=3,6 ; P=$ 0.2475 ) have any effect on catalase activity. However, catalase activity decreased significantly among the three sampling dates $(F=31.44 ; \mathrm{df}=2,48 ; P<0.0001)$ on all four cereals and all three infestations (Fig. 3). The results indicate that neither $R$. padi nor D. noxia feeding affected catalase activity in cereal leaves.

Polyphenol Oxidase Activity. As with catalase activity, polyphenol oxidase activity was not significantly affected by either three-way (i.e., cereal-by-infesta- 

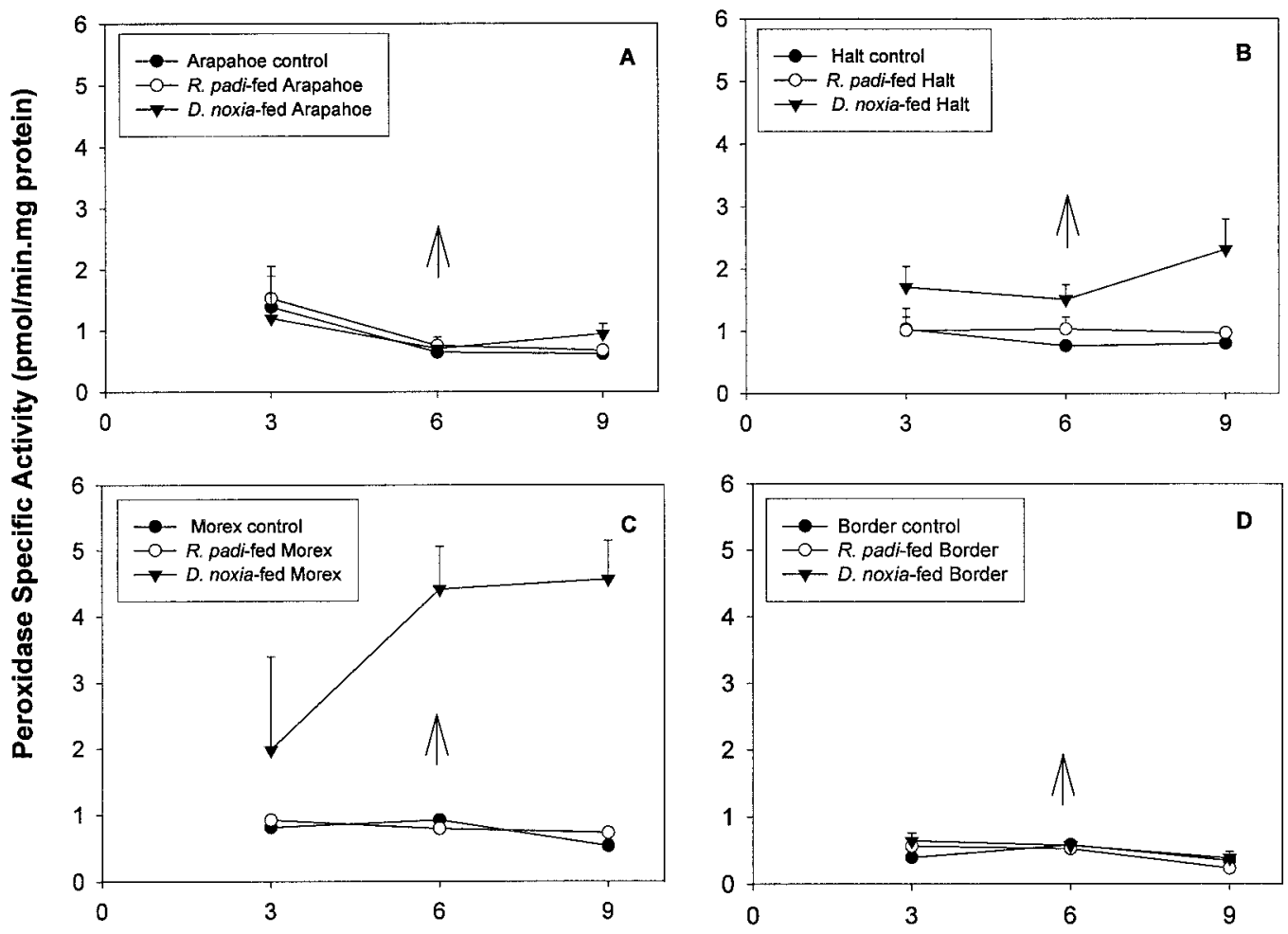

Days after infestation

Fig. 2. Peroxidase specific activity $\left(\mathrm{pmol} \cdot \mathrm{min}^{-1} \cdot \mathrm{g}\right.$ protein ${ }^{-1}$ ) from aphid-infested (i.e., 0, 20 R. padi, or 20 D. noxia) cereal leaves on 3,6, and $9 \mathrm{~d}$ after the initial infestation. Error bars represent standard error of the mean (SEM) for a data point $(n=3)$. (A) Arapahoe wheat (D. noxia susceptible). (B) Halt wheat (D. noxia resistant). (C) Morex barley (D. noxia susceptible). (D) Border oat (D. noxia resistant). R. padi denotes the bird cherry-oat aphid, Rhopalosiphum padi L., and D. noxia denotes the Russian wheat aphid, Diuraphis noxia (Mordvilko). The arrows on the graphs indicated when chlorosis was first observed.

tion-by-sampling date) interaction $(F=0.61 ; \mathrm{df}=12$, $48 ; P=0.8220)$, or infestation type $(F=2.85 ; \mathrm{df}=2$, $16 ; P=0.0876)$, or cereal type $(F=4.04 ; \mathrm{df}=3,6 ; P=$ 0.0687 ) (Fig. 4). Polyphenol oxidase activity also varied significantly among the sampling dates $(F=32.47$; $\mathrm{df}=2,48 ; P<0.0001)$. The leaves from the first sampling date $(3 \mathrm{~d})$ showed the highest polyphenol oxidase activity, whereas the leaves from the last sampling date $(9 \mathrm{~d})$ showed the least polyphenol oxidase activity. The results indicate that the types of infestations did not have any significant impact on polyphenol oxidase activity. The decrease in both catalase and polyphenol oxidase activities among the sampling dates might be the results of normal cereal leaf growth.

\section{Discussion}

Diuraphis noxia caused more damage than R. padi on Arapahoe wheat and Morex barley measured by leaf rolling and chlorosis ratings and fresh leaf weight in comparison with Halt wheat and Border oat. This supports our previous finding that $D$. noxia prefers to feed and reproduce more nymphs on the susceptible Arapahoe wheat and Morex barley than on the resis- tant Halt wheat and Border oat (Ni et al. 1998). Furthermore, aphid population data showed that D. noxiaresistant Halt wheat might not necessarily be R. padiresistant. This observation needs to be further examined.

Although D. noxia is a chlorosis-eliciting species and R. padi is a nonchlorosis-eliciting species, their feeding caused similar increases in total leaf protein content on all cereals regardless of their degree of resistance to $D$. noxia. This finding indicates that both symptomatic and asymptomatic aphid feeding induces protein biosynthesis in cereals, and is in concurrence with previous reports on plant defensive responses to pathogens and other herbivores. The induction of proteins in plant tissues by infestations of herbivores or infections of pathogens has been demonstrated by numerous studies, and this special type of the protein has been termed "pathogenesis-related" (or PR) protein (Hildebrand et al. 1989, Hammerschmidt and Nicholson 1999). The increase in total protein content of aphid-infested cereals compared with the control cereals suggests that aphid feeding induced local accumulation of proteins on aphid-infested cereal leaves. 


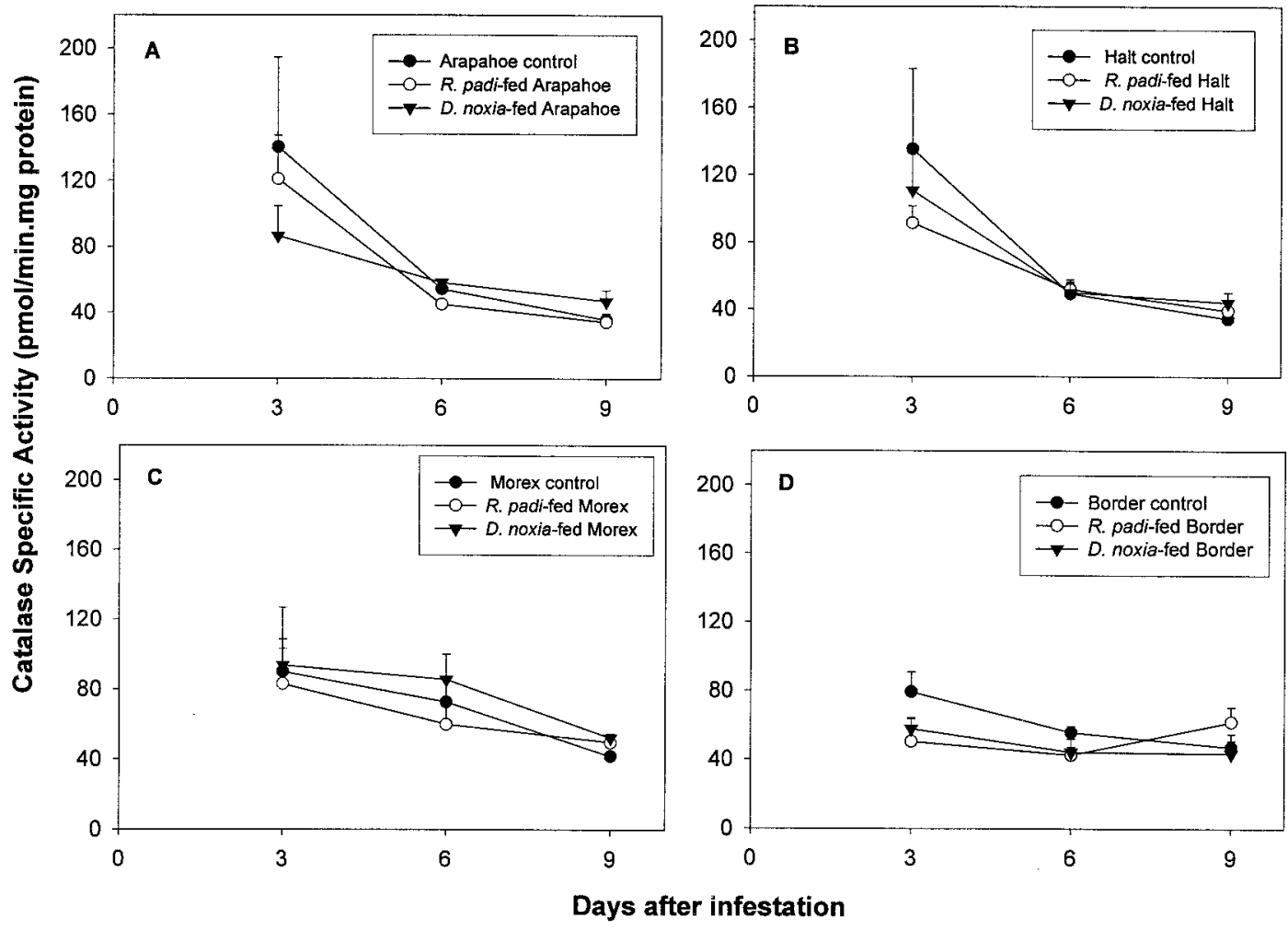

Fig. 3. Catalase specific activity (pmol $6 \mathrm{~min}^{-1} 6 \mathrm{mg}$ protein ${ }^{-1}$ ) from aphid-infested (i.e., 0, 20 R. padi, or 20 D. noxia) cereal leaves on 3,6, and $9 \mathrm{~d}$ after the initial infestation. Error bars represent standard error of the mean (SEM) for a data point $(n=3)$. (A) Arapahoe wheat (D. noxia susceptible). (B) Halt wheat (D. noxia resistant). (C) Morex barley (D. noxia susceptible). (D) Border oat (D. noxia resistant). R. padi denotes the bird cherry-oat aphid, Rhopalosiphum padi L., and D. noxia denotes the Russian wheat aphid, Diuraphis noxia (Mordvilko).

The induction of protein content in aphid-infested leaves indicates that plants are likely to show enzymatic responses to aphid feeding. However, our findings disagree with the report by Van der Westhuizen and Pretorius (1995) who demonstrated that D. noxia feeding elicited more than a twofold water soluble protein content reduction as early as 2 -d infestation when it was compared with the control leaves. The difference between our report and that of Van der Westhuizen and Pretorius (1995) could be the result of different initial aphid infestation levels. We used 20 apterous $D$. noxia for the current study, however, the level of the initial aphid infestation was not described by Van der Westhuizen and Pretorius (1995).

The increase in peroxidase activity occurred before leaf chlorosis development on D. noxia-infested Halt wheat and Morex barley leaves. This finding indicates that damage symptom development on these two cereals may be related to $D$. noxia-elicited plant oxidative responses, because the nonsymptomatic $R$. padi did not elicit any significant increases of oxidative enzyme activities. The findings from the current study support a number of previous reports that have demonstrated that oxidative enzymes (e.g., peroxidase, catalase, and polyphenol oxidase) in plants play an important role in responding to biotic and abiotic stresses (Hildebrand et al. 1986; Zhang and Kirkham 1994; Felton et al. 1994a. 1994b). In addition, Duffey and Felton (1991) have demonstrated in vitro that the peroxidase activity is dependent on a supply of hydrogen peroxide. The production of radical or reduced intermediates (e.g., hydrogen peroxide, superoxide, and the hydroxyl radicals) in plants is the result of metabolic reactions involving oxygen (Daub et al. 1998). To understand hydrogen peroxide production in plants, further examination of superoxide dismutase and other related enzyme activities will be necessary because superoxide dismutase is responsible for scavenging reactive oxygen intermediates in plants to form hydrogen peroxide.

A number of reports have suggested that peroxidases play an important role in both herbivore and pathogen resistance in crop plants (Dowd and Lagrimini 1997, Chittoor et al. 1999, Constabel 1999). Peroxidases are the key enzymes in plant cell wall-building processes, such as peroxidase-mediated oxidation of hydroxycinnamyl alcohols into free radical intermediates, phenol oxidation, polysaccharide cross-linking, cross-linking of extensin monomers, lignification, and suberization (Chittoor et al. 1999). The final products of such enzymatic activities would be considered anti-nutritive (or anutritive) because they cannot be 

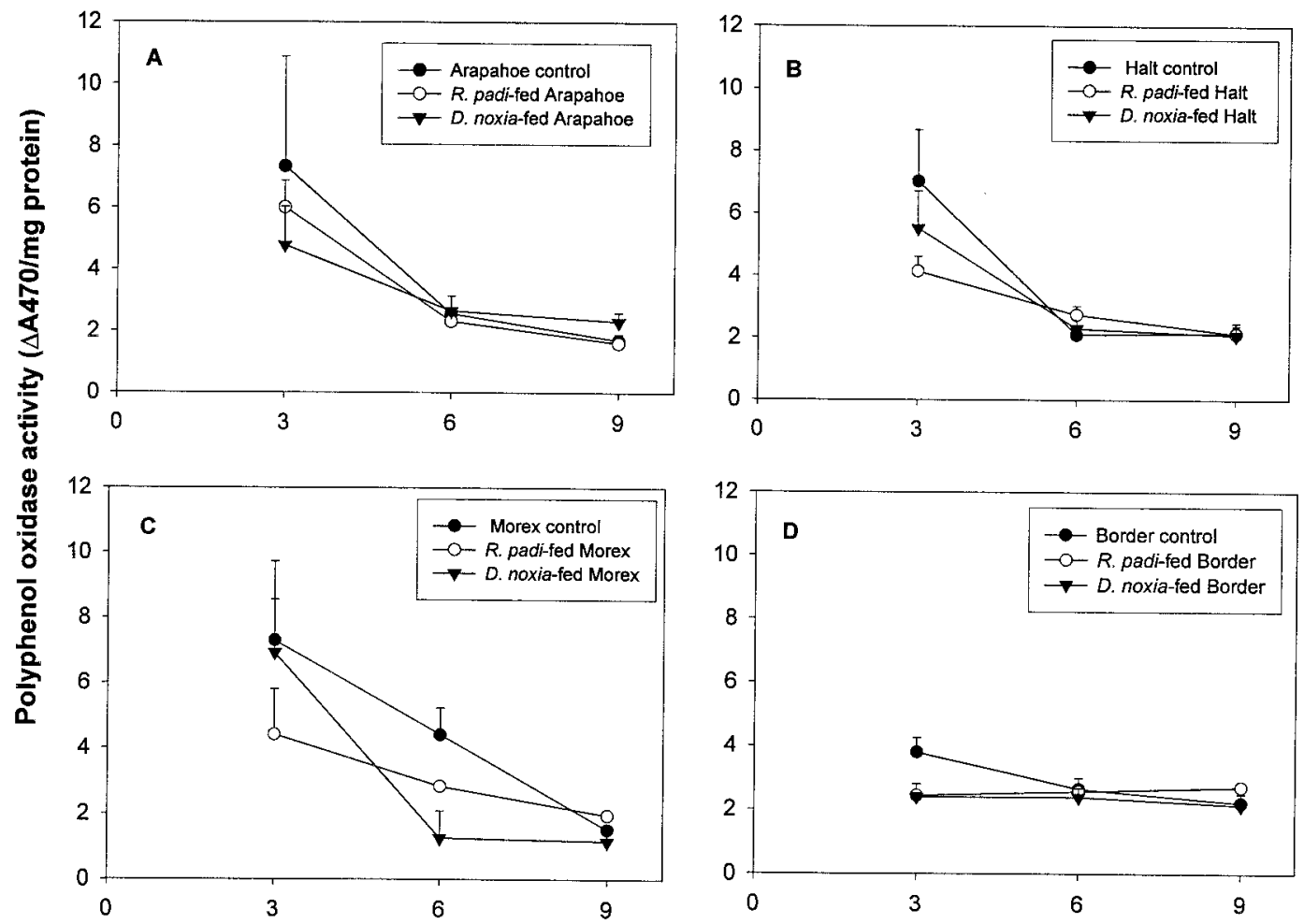

Days after infestation

Fig. 4. Polyphenol oxidase activity $\left(\Delta \mathrm{A}_{470} \cdot \mathrm{min}^{-1} \cdot \mathrm{mg}\right.$ protein $\left.{ }^{-1}\right)$ from aphid-infested (i.e., 0, 20 R. padi, or 20 D. noxia) cereal leaves on 3, 6, and $9 \mathrm{~d}$ after the initial infestation. Error bars represent standard error of the mean (SEM) for a data point $(n=3)$. (A) Arapahoe wheat (D. noxia susceptible). (B) Halt wheat (D. noxia resistant). (C) Morex barley (D. noxia susceptible). (D) Border oat (D. noxia resistant). R. padi denotes the bird cherry-oat aphid, Rhopalosiphum padi L., and D. noxia denotes the Russian wheat aphid, Diuraphis noxia (Mordvilko).

efficiently digested and assimilated by insects (Duffey and Stout 1996, Constabel 1999). Enhancement of peroxidase isozyme activity in maize (Zea mays L.) increases resistance to herbivores and pathogens (Dowd and Lagrimini 1997). However, Dowd and Lagrimini (1997) state that peroxidase functions in plants are complicated and the role of peroxidase in plant resistance to its pests is sometimes controversial because variations have been observed among different plant-insect systems, as well as laboratory studies may not reflect field conditions. Our data reflect these contrasting paradigms; for instance, D. noxia-infested Border oat plants showed the least changes of peroxidase, catalase, and polyphenol oxidase activities when compared with wheat and barley. Thus, $D$. noxia-resistant mechanism in Border oat is not necessarily related to oxidative enzymes. Wheat resistance to $D$. noxia is likely to be positively correlated to peroxidase activity because $D$. noxia-infested resistant Halt showed a greater peroxidase activity than susceptible Arapahoe. Conversely, Morex barley susceptibility is likely to be positively related to the increase of peroxidase activities. Such contrasting differences between $D$. noxia-resistant Halt wheat and $D$. noxiasusceptible Morex barley may be the result of genetic differences in their metabolic pathways to scavenge oxidative radicals. The interruption of the balance of reduction and oxidation functions (i.e., redox system) in plants against sap-feeding insects has been designated as "the redox hypothesis" in aphid-plant interactions (Miles and Oertli 1993). Although Miles and Oertli (1993) suggest that the change of oxidative activities is a natural part of plant defense against insect herbivory, the findings of our current study using the chlorosis-eliciting $D$. noxia and the nonchlorosis-eliciting $R$. padi indicate that cereal plant resistance against the aphid feeding might be complicated biochemical processes that need to be further examined. The results from this experiment will serve as the baseline information for us to understand the proteins involved in the defensive responses of plants to sapfeeding herbivores, and to ultimately identify enzymatic marker(s) for the screening of plant germplasms for herbivore resistance.

\section{Acknowledgments}

We thank J. Littlefield, J. Storlie, and Y. Wang (Montana State University) for their assistance in conducting the experiments. We also thank J. Martin for his advice on statistical 
analysis. We greatly appreciate the critical review of the manuscript by W. Morrill, K. O’Neill, D. Weaver, and anonymous reviewers. This work was supported in part by an Interdisciplinary Research Grant (NEB 17-064) from the Agriculture Research Division, the University of NebraskaLincoln, a USDA-NRICGP grant (99-3502-8628), and by the Center for Biotechnology, UNL, funded through Nebraska Research Initiative. This is Journal Series No. 2000-49 from the Montana Agricultural Experiment Station.

\section{References Cited}

Bollag, D. M., and S. J. Edelstein. 1991. Protein concentration determination, pp. 45-69. In D. M. Bollag and S. J. Edelstein (eds.), Protein methods. Wiley, New York.

Burd, J. D., R. L. Burton, J. A. Webster. 1993. Evaluation of Russian wheat aphid (Homoptera: Aphididae) damage on resistant and susceptible hosts with comparisons of damage ratings to quantitative plant measurements. J. Econ. Entomol. 86: 974-980.

Chance, B, and A. C. Maehly. 1955. Assay of catalase and peroxidase, pp. 765-775. In S. P. Coldwick and N. O. Kaplan (eds.), Methods in enzymology, vol. 2. Academic, New York.

Chittoor, J. M., J. E. Leach, and F. F. White. 1999. Induction of peroxidase during defense against pathogens, pp. 171193. In S. K. Datta and S. Muthukrishnan (eds.), Pathogenesis-related proteins in plants. CRC, Boca Raton, FL.

Cochran, W. G., and G. M. Cox. 1957. Experimental design. Wiley, New York.

Constabel, C. P. 1999. A survey of herbivore-inducible defensive proteins and phytochemicals, pp. 137-166. In A. A. Agrawal, S. Tuzun, and E. Bent (eds.), Induced plant defenses against pathogens and herbivores - chemistry, ecology and agriculture. APS Press, The American Phytopathological Society, St. Paul, MN.

Daub, M. E., M. Ehrenshaft, A. E. Jenns, and K.-R. Chung. 1998. Active oxygen in fungal pathogenesis of plants: the role of Cercosporin in Cercospora Diseases, pp. 31-56. In J. T. Romeo, K. R. Downum, and R. Verpoorte, [eds.], Advances in phytochemistry, vol. 32. Phytochemical signals and plant-microbe interactions. Plenum Press, New York.

Dowd, P. F., and L. M. Lagrimini. 1997. The role of peroxidase in host insect defenses, pp. 195-223. In N. Carozzi and M. Koziel (eds.), Advances in insect control: the role of transgenic plants. Taylor and Francis, Bristol, PA.

Duffy, S. S., and G. W. Felton. 1991. Enzymatic anutritive defenses of the tomato plants against insects, pp. 167-197. In P. A. Hedin (ed.), Naturally occurring pest bioregulators. ACS symposium Series 449. Dallas, 1989. American Chemical Society, Washington, DC.

Duffy, S. S., and M. J. Stout. 1996. Anutritive and toxic compounds of plant defense against insects. Arch. Insect Biochem. Physiol. 32: 3-37.

Felton, G. W., K. Donato, R. J. Del Vecchio, and S. S. Duffey. 1989. Activation of plant foliar oxidases by insect feeding reduces nutritive quality of foliage for noctuid herbivores. J. Chem. Ecol. 15: 2667-2694.

Felton, G. W., C. B. Summers, and A. J. Mueller. 1994a. Oxidative responses in soybean foliage to herbivory by bean leaf beetle and three-cornered alfalfa leafhopper. J. Chem. Ecol. 20: 639-650.

Felton, G. W., J. L. Bi, C. B. Summers, A. J. Mueller, and S. S. Duffey. 1994b. Potential role of lipoxygenases in defense against insect herbivory. J. Chem. Ecol. 20: 651-666.

Hammerschmidt, R., and R. L. Nicholson. 1999. A survey of plant defense responses to pathogens, pp. 55-71. In A. A. Agrawal, S. Tuzun, and E. Bent (eds.), Induced plant defenses against pathogens and herbivores - chemistry, ecology and agriculture. APS Press, The American Phytopathological Society, St. Paul, MN.

Hildebrand, D. F., J. G. Rodriguez, G. C. Brown, K. T. Luu, and C. S. Volden. 1986. Peroxidative responses of leaves in two soybean genotypes injured by twospotted spider mites (Acari: Tetranychidae). J. Econ. Entomol. 79: 14591465.

Hildebrand, D. F., J. G. Rodriguez, C. S. Legg, G. C. Brown, and G. Bookjans. 1989. The effects of wounding and mite infestation on soybean leaf lipoxygenase levels. $\mathrm{Z}$. Naturforsch. 44c: 655-659.

Hori, K., A Wada, and T. Shibuta. 1997. Changes in phenoloxidase activities of the galls on leaves of Ulmus dadvidana formed by Tetraneura fusiformis (Homoptera: Eriosomatidae). Appl. Entomol. Zool. 32: 365-371.

Miles, P. W., and J. J. Oertli. 1993. The significance of antioxidants in the aphid-plant interaction: the redox hypothesis. Entomol. Exp. Appl. 67: 275-283.

Neter, J., W. Wasserman, and M. H. Kutner. 1985. Nested design III, pp. 1000-1030. In J. Neter, W. Wasserman, and M. H. Kutner (eds.), Applied linear statistical models. Irwin, Homewood, IL

Ni, X., S. S. Quisenberry, B. D. Siegfried, and K. W. Lee. 1998. Influence of cereal leaf epicuticular wax on Diuraphis noxia probing behavior and nymphoposition. Entomol. Exp. Appl. 89: 111-118.

SAS Institute. 1989. SAS/STAT user's guide. SAS Institute, Cary, NC.

Van der Westhuizen, A. J., and Z. Pretorius. 1995. Biochemical and physiological responses of resistant and susceptible wheat to Russian wheat aphid infestation. Cereal Res. Commun. 23: 305-313.

Webster, J. A., C. A. Baker, and D. R. Porter. 1991. Detection and mechanism of Russian wheat aphid (Homoptera: Aphididae) resistance in barley. J. Econ. Entomol. 84: $669-673$.

Zadoks, J. C., T. T. Chang, and C. F. Konzak. 1974. A decimal code for the growth stages of cereals. Weed Res. 14: 415-421.

Zhang, J., and M. B. Kirkham. 1994. Drought-stress-induced changes in activities of superoxide dismutase, catalase, and peroxidase in wheat species. Plant Cell Physiol. 35: $758-791$ 2001. 